\title{
THE RUIE OF RULES
}



Morality,

Rules,

Larry Alexander and Emily Sherwin

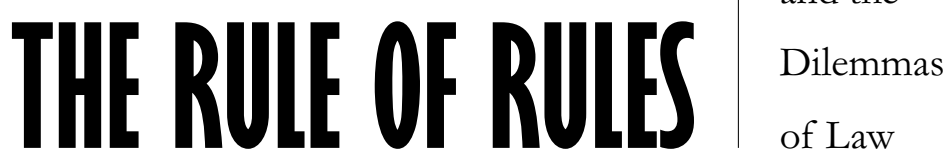

and the

DUKE

UNIVERSITY

PRESS

DUR HAM

AND LONDON

2001 
(C) 200I Duke University Press

All rights reserved

Printed in the United States

of America on acid-free paper @

Designed by Rebecca Giménez

Typeset in Monotype Garamond

by Tseng Information Systems

Library of Congress Catalogingin-Publication Data appear on the last printed page of this book. 